\title{
GERAKAN DAKWAH JAMA'AH TABLIGH DI KALANGAN WANITA DALAM PEMBINAAN KELUARGA MUSLIM
}

\author{
Muhamad Bisri Mustofa \\ Institut Agama Islam Agus Salim Metro \\ Jl. Brigjend. Sutiyoso No. 7, Kota Metro, 34111, Lampung \\ muhamadbisrimustofa@gmail.com
}

\begin{abstract}
Jama'ah Tabligh is a missionary movement that has the concept of movement with the method of da'wah and tabligh. The characteristics of the Jama'ah Tabligh propagation movement are: pure and authentic (dzâtiyyâh), which is authentic as God's calling, encouraging progress (taqaddûmîah), namely progress that continues to uphold morality, universal values (shamîlâhi) covering all aspects of life, integrating progress three systems of life (manhaj al hayat), emphasizing the principles of the sublime religion and distancing themselves from the differences of the schools. In connection with the above statement, the author would like to know the Tablighi Jama'ah movement among women in fostering Muslim families spearheaded by women who have been Khurûj with their husbands, then what about affection for their families especially children left behind, and liability obligations for families who left. Because on the other hand he also has to carry out his duties as a parent as it should be, including giving love to children, educational guidance, religion towards children and spiritual and physical support for children left by their parents when Khurûj. The issue to be investigated is how is the Tablighi Jama'ah movement among women in developing Muslim families? What material is the da'wah used by the Tablighi Jama'ah in fostering Muslim families? And what are the obstacles to the Tablighi Jama'ah movement in fostering Muslim families? The purpose of this study was to determine the character of the Tablighi Jama'ah movement among women in family formation, find out the material used, and find out the constraints of the Jama'ah Tabligh propaganda movement in the formation of Muslim families. This study seeks to provide an interpretation of the phenomena of the Tablighi Jama'ah, of course in accordance with the predetermined research focus and also uses relevant theories to be able to uncover the propaganda movement of the Tablighi Jama'ah among women in fostering Muslim families. The theory is a functional structural theory, family theory and family according to Islamic teachings
\end{abstract}

\section{Keywords: Da'wah Movement, Tablighi Jama'ah, Women, Family Development}

\begin{abstract}
Abstrak
Jama'ah Tabligh merupakan gerakan dakwah yang mempunyai konsep gerakan dengan metode dakwah dan tabligh. Adapun karakteristik gerakan dakwah Jama'ah Tabligh yaitu : murni dan autentik (dzâtiyyâh), yakni autentik sebagai panggilan Tuhan, mendorong kemajuan (taqaddûmîyah), yakni kemajuan yang tetap menjunjung tinggi nilai-nilai moralitas, universal (syamîlâhi) mencakup semua aspek kehidupan, memadukan tiga sistem hidup (manhaj al hayat), menekankan prinsip-prinsip agama yang luhur dan menjauhkan diri dari perbedaan mazhab. Berkaitan dengan pernyataan di atas, penulis ingin mengetahui gerakan dakwah Jama'ah Tabligh di kalangan wanita dalam pembinaan
\end{abstract}


keluarga muslim yang dipelopori oleh wanita yang pernah Khurûj dengan suaminya, lalu bagaimana dengan kasih sayang terhadap keluarganya terutama anak yang ditinggalkan, dan kewajiban nafkah bagi keluarga yang di tinggalkan. Karena disisi lain ia juga harus menjalankan kewajiban sebagai orang tua sebagai mestinya, antara lain memberikan kasih sayang terhadap anak, bimbingan pendidikan, agama terhadap anak dan nafkah lahir batin bagi anak yang di tinggalkan oleh orang tuanya ketika Khurûj. Adapun masalah yang akan diteliti adalah bagaimana gerakan dakwah Jama'ah Tabligh di kalangan wanita dalam pembinaan keluarga muslim? Apa materi dakwah yang digunakan Jama'ah Tabligh dalam pembinaan keluarga muslim? Dan apa saja faktor kendala gerakan Jama'ah Tabligh dalam pembinaan keluarga muslim?. Tujuan penelitian ini yaitu untuk mengetahui karakter gerakan dakwah Jama'ah Tabligh di kalangan wanita dalam pembinaan keluarga, mengetahui materi yang digunakan, dan mengetahui faktor kendala gerakan dakwah Jama'ah Tabligh dalam pembinaan keluarga muslim. Penelitian ini berusaha untuk memberikan penafsiran terhadap fenomena-fenomena yang Jama'ah Tabligh, tentunya sesuai dengan focus penelitian yang telah ditentukan dan juga menggunakan teori yang relevan untuk bisa mengungkap gerakan dakwah Jama'ah Tabligh di kalangan wanita dalam pembinaan keluarga muslim. Teori tersebut adalah teori structural fungsional, teori keluarga dan keluarga menurut ajaran Islam.

Kata Kunci : Gerakan Dakwah, Jama'ah Tabligh, Wanita, Pembinaan Keluarga

How to Cite :

MB, Mustofa. (2019). Gerakan Jama'ah Tabligh Di Kalangan Wanita Dalam Pembinaan Keluarga. Mau'idhoh Hasanah : Jurnal Dakwah dan Ilmu Komunikasi, 1 (1), 1-2.

\section{Pendahuluan}

Dakwah merupakan tugas bagi setiap umat Islam, yang dalam menjalaninya tidaklah semudah membalikan telapak tangan. Di lapangan bagitu banyak persoalan dan tan tangan. Mulai dari masalah ketidaktahuan umat terhadap syari'at hingga perselisihan antar ummat Islam dan antar ummat beragama. Disamping itu perkembangan, budaya, ekonomi, pemerintahan, dan teknologi yang tumbuh begitu pesat.

Dari perkembangan zaman tersebut, berdampak pada dakwah yang terjadi pada diri umat, maka metode dakwah dalam berdakwah juga perlu dikembangkan. Di dalam Al-Qur'an telah di jelaskan beberapa metode dakwah yaitu dengan metode bil hikmah', yaitu memilah dan menyelaraskan teknik dakwah dengan kondisi objek mad'u, al-mauidzâtul hasanah, dengan penuh kasih sayang dan dengan penuh kelembutan. Selanjutnya dangan al-mujadalah billatî hiya ahsan, adalah tukar pendapat yang dilakukan oleh dua belah pihak secara sinergis, yang tidak melahirkan permusuhan dengan tujuan agar lawan menerima pendapat yang diajukan dengan mengajukan argumentasi dan bukti yang kuat.

Sesungguhnya Allah Swt meletakan kebahagian manusia baik laki-laki maupun wanita di dalam amalan agama yang sempurna, yakni dengan sejauh mana manusia tersebut mentaati perintah Allah Swt dan Rasul-Nya. Sebagaimana firman Allah Swt :

1 Wahyu Ilahi, M. Munir, Manajemen Dakwah, (Jakarta : Prenada Media, 2006), Cet. Ke-1, h. 31 


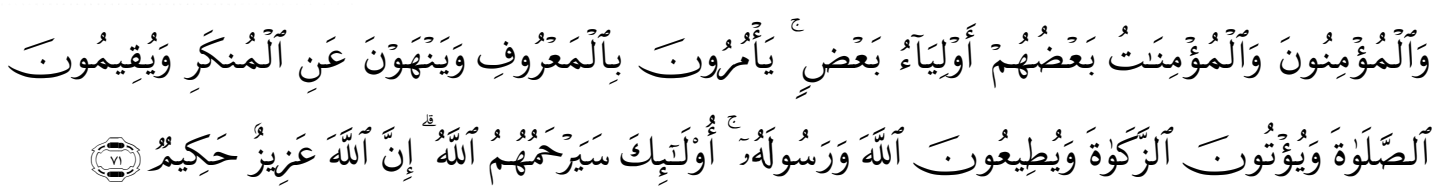

Artinya : "Dan orang-orang yang beriman, lelaki dan perempuan, sebahagian mereka (adalah) menjadi penolong bagi sebahagian yang lain. mereka menyuruh (mengerjakan) yang ma'ruf, mencegah dari yang munkar, mendirikan shalat, menunaikan zakat dan mereka taat pada Allah dan Rasul-Nya. mereka itu akan diberi rahmat oleh Allah; Sesungguhnya Allah Maha Perkasa lagi Maha Bijaksana." (Qs. At-Taubah [9] : 71)²

Ketika Islam datang, maka lenyaplah semua kezhaliman yang dahulu sering menimpa kaum wanita, dan Islam mulai mengembalikan mereka kepada derajat yang sama sesungguhnya sebagai manusia yang memiliki kemuliaan sebagaimana kaum laki-laki. ${ }^{3} \mathrm{Hal}$ ini membuat suatu ikatan yang baik antara laki-laki dan wanita sebagaimana perintah Allah Swt yang ditunjukan kepada seluruh manusia dimuka bumi agar saling mengetahui siapa dan bagaimana seharusnya individu berbuat sesuai dengan ta'bîat yang telah ditetapkan. Sebagaimana firman Allah Swt :

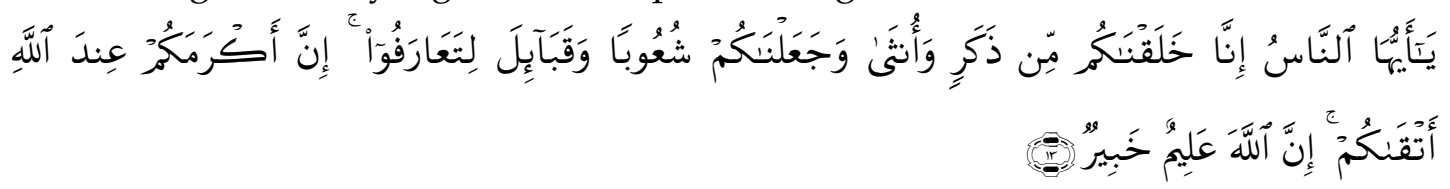

Artinya : "Wahai manusia, sesungguhnya Kami telah menciptakan kalian dari jenis laki-laki dan jenis perempuan." (Qs. Al-Hujarat [49] : 13) ${ }^{4}$

Dalam ayat ini Allah Swt menyebutkan bahwa kaum wanita memiliki kesamaan dalam awal penciptaannya. Sebagaimana ia juga memiliki kesaam dengan kaum lelaki dalam hal pahala dan siksa atas amal perbuatanya. Sebagaimana firman Allah Swt :

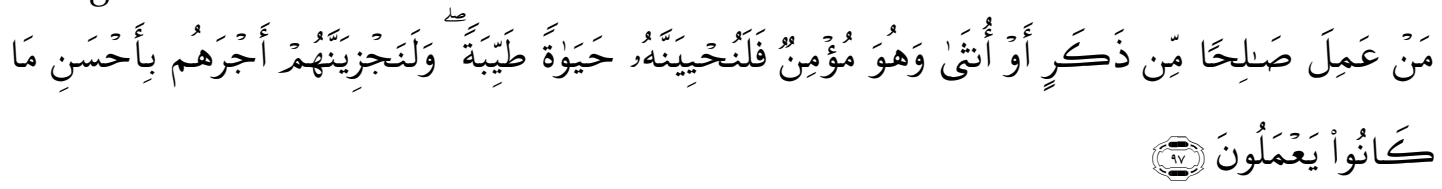

Artinya : "Barangsiapa yang beramal shalih baik laki-laki maupun wanita dan ia seorang mu'min, maka Kami pasti akan memberikan kepada mereka kehidupan yang baik dan pasti Kami memberi pahala dengan yang lebih baik dari apa yang telah mereka lakukan." (Qs. An-Nahl [16] : 97) 5

Dalam ayat lain Allah Swt berfirman :

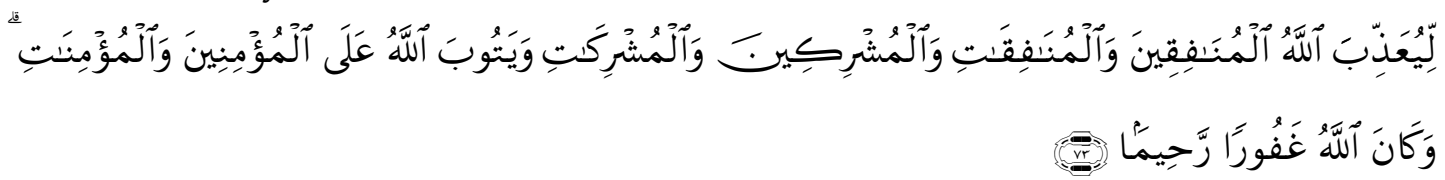

Artinya : "Agar Allah memberi balasan azab kepada orang-orang munafik laki-laki dan perempuan juga kepada orang-orang musyrik laki-laki dan perempuan dan Allah menerima taubat orang-orang mu'min pria dan wanita, dan Allah Maha Pengampun lagi Maha Penyayang." (Qs. Al-Ahzab [33] : 73).

\footnotetext{
2 Departemen Agama RI, Al-Qur'an dan Terjemah, (Jakarta : Maghafirah Pustaka, 2006), h. 198

${ }^{3}$ Musthafa Sayani, Kemulian Wanita Shalihah, (Bandung : Pustaka Ramadhan, 2004), Cet. Ke-2,
} h. 1 
Dalam hal rumah tangga, Allah telah menetapkan hak-hak kaum wanita (para isteri) atas para suaminya yang harus dipenuhi oleh mereka sesuai dengan kemampuan mereka yang jika diringkas hak-hak isteri yang harus dipenuhi oleh suami adalah sebagai berikut: 6

Pertama, hak untuk memperoleh muasyarah (pergaulan) yang ma'ruf dari suaminya, sebagaimana firman-Nya :

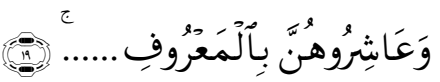
$: 19)^{7}$

Artinya : "Dan pergaulilah isteri-isterimu dengan ma'ruf (baik)." (Qs. An-Nisa [4]

Kedua, hak untuk memperoleh mahar yang harus ditunaikan oleh suaminya dengan hati yang tulus, sebagimana firman-Nya :

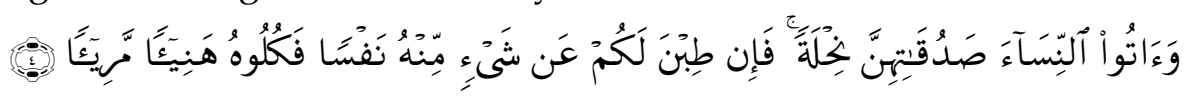

Artinya : "Dan berikanlah kepada wanita-wanita (yang kamu nikahi) mahar-mahar mereka sebagai pemberian dengan penuh kerelaan. Kemudian jika mreka menyerahkan kepadamu sebagian dari mahar dengan senang hari, maka makanlah (ambilah) pemberian itu (sebagai makanan) yang sedap lagi baik akibatnya". (Qs. An-Nisa [4] : 4)8

Ketiga, Allah menjadikan para isteri sebagai pemimpin anak-anaknya dirumah suaminya berhak menyuruh dan melarang mereka. Nabi Saw bersabda "...dan isteri adalah pemimpin di rumah suaminya dan ia akan ditanya tentang (anak-anak) yang dipimpinnya."

Keempat, hak untuk memperoleh nafkah yang baik dari suaminya. Disamping itu, kaum wanita diberi andil oleh Allah untuk bekerja sama dan membantu kaum laki-laki dalam pengalaman dan perjuangan agama. Sebagaimana firman-Nya :

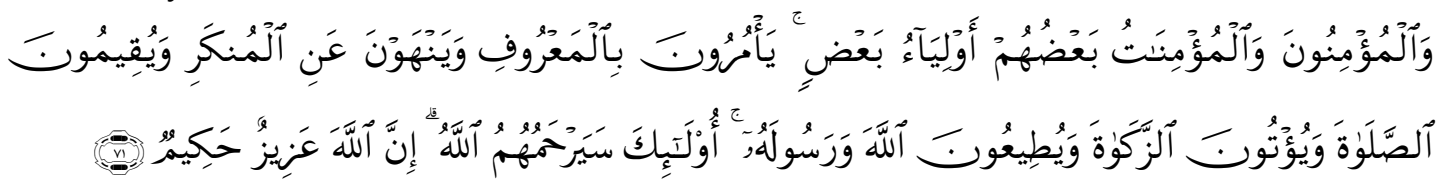

Artinya :"Dan orang-orang yang beriman, laki-laki dan perempuan, sebagian mereka menjadi penolong sebagian yang lain. Mereka menyuruh kepada yang ma'ruf dan mencegah dari yang mungkar, mendirikan shalat, membayar zakat, dan mereka taat kepada Allah dan Rasul-Nya. Mereka itu akan diberi rahmat oleh Allah. Sesungguhnya Allah Maha Perkasa lagi Maha Bijaksana." (Qs. At-Taubah [9] : 71). ${ }^{9}$

Populasi penduduk dunia saat ini lebih banyak kaum wanita dari pada lakilaki, sedangkan jumlah anak-anak lebih banyak dari pada wanita. Apabila kaum wanita memahami dan mempunyai kesadaran beragama, dia akan membuat suasana agama di rumah, demi mewujdukan anak-anak yang shalih-shalihah; alim dan alimah; mujahid-mujahidah. ${ }^{10}$

Para Rasul yang mendapat dukungan dari istri nya terbukti berhasil dalam dakwah mereka, dengan hasil berupa panigkut dan tersebarnya ajaran tauhid

${ }^{6}$ Musthafa Sayani, Kemulian Wanita Shalihah..., Op.cit., h. 2

7 Departemen Agama RI, Al-Qur'an dan Terjemah..., Op.cit., h. 80

8 Ibid., h. 77

${ }^{9}$ Ibid., h. 198

10 Maulana Muhammad Manshur, Masturoh, Gerakan Dawkah di Kalangan Wanita, (Bandung : Pustaka Ramadhan, 2007), Cet. Ke-1, h. 3 
(ketuhanan) kepada ummat, misalnya Nabi Ibsrahim As dan Nabi Muhammad Saw. Ajaran agama berkembang cukup luas dan mencakup berbagai daerah. Sedangkan Nabi dan Rasul yang tidak di dukung oleh istri, seperti Nabi Nuh As, Nabi Luth As maka sedikit pengikut dan ajaran ketuhana berkembang dalam sekup yang kecil.

Oleh karena itu tugas dakwah bukan hanya tanggung jawab seorang lakilaki, namun wanita juga memiliki tanggung jawab yang sama. Ketika Nabi Muhammad Saw diangkat menjadi seorang Rasul, yang pertama kali beriman adalah seorang wanita, yaitu Khadijah r.ha, istri Rasulullah Saw.

Keluarga merupakan madrasah awal bagi seorang anak berkembang dan belajar, dan pemegang kendali pada pendidikan awal (tarbiyatul ula) bagi seorang anak adalah kepada ibu. Tugas ibu diantaranya mengurus rumah tangga, mendidik anak, dan tugas seorang ayah adalah dengan mencari nafkah bagi kemaslahatan keluarga. Semakin baik seorang ibu maka akan semakin baik pendidikan dan pengajaran bagi anak. Bagitu pula dengan keshalihan ibu akan membawa pengaruh bagi seorang anak.

Target dakwah dalam gerakan dakwah dikalangan wanita oleh Jama'ah Tabligh adalah dengan metode khurûj fî sabîlillâh, adalah metode dakwah dengan cara meluangkan waktu, harta, dan diri untuk memperbaiki diri dengan amalanamalan agama yang sesuai dengan Al-Qur'an dan As-sunnah dan mencontoh dakwah para Sahabar ra. Metode dakwah yang dilakukan oleh Jama'ah Tabligh terhadap para wanita ini dengan cara membawa mahram seperti istri, anak perepuan yang sudah baligh, adik atau kakak perempuan atau ibu.

Dakwah dengan metode khurûj fì sabîlillâh di kalangan wanita dengan meluangkan waktu secara bertahap sebagai berikut : selama 3 hari untuk setiap 3 bulan, 10 atau 15 hari untuk setiap tahun, 40 hari untuk setiap 3 tahun dan 2 bulan menuju negara India, Pakistan. Kedua negara tersebut merupakan perintis kembali usaha dakwah dengan Manhaj Nubûwwah (jalur kenabian), menyesuaikan dengan dakwah para Nabi, Rasul dan para Sahabat ra. Dengan cara mendatangi ummat, mengetuk setiap rumah untuk bersama-sama mengamalkan agama, tidak berbicara masalah politik, dan tidak meminta upah.

Target usaha dakwah jama'ah tabligh di kalangan wanita dengan metode khurûj fî sabîlillâh adalah dengan membentuk wanita sebagai Murobîyyah (guru), Alimah (berilmu), 'Abîdah (ahli ibadah), Da'iyah (pendakwah), dan Khadîmah (pelayan), Zâhidah (sederhana) bagi keluarga. Dalam penelitian ini akan dijelaskan bagaimana gerakan dakwah jama'ah tabligh di kalangan wanita dalam pembinaan keluarga muslim.

Dalam pembinaan keluarga yang dilakukan oleh jama'ah tabligh, pertama adalah dengan mengajak wanita untuk keluar di jalan Allah (khurûj fí sabîlillâh) dan membentuk para wanita menjadi murobiyyah atau seorang guru, seorang wanita ketika keluar di jalan Allah mendapatkan materi tentang berbagai hal penting dalam membina keluarga seperti adab-adab keseharian (tidur, bersuci, berpakaian, mencuci, memasak, mengurus anak, dan lain lain). Seluruh materi tersebut disampaikan kembali kepada anak dan anggota keluarga yang lain setelah selesai melaksanakan khurûj fî sabîlillâh. Selanjutnya seorang wanita diminta bertanggung jawab terhadap anaknya agar mengajarkan kebaikan, mengenalkan anak tersebut kepada Allah, mengajari mengaji, dan mengajari adab-adab keseharian yang sesuai dengan syariat Islam. 
Selanjutnya membentuk seorang wanita menjadi alimah atau seorang yang berilmu, dalam program khurûj fî sabîlillâh selain mendengarkan beberapa nasihat tentang wanita, juga dibacakan ta'lim tentang keutamaan dalam beramal, menggunakan kitab Fadhail Amal, Muntakhab Ahadits (Kumpulan Hadits-Hadits), Fadhilah Sedekah agar menambah ilmu agama. Dengan dibacakan oleh salah seorang wanita yang sedang khurûj fî sabîlillâh, dan wanita yang lainnya membawa sifat-sifat Tasdiq wal yaqîn (membenarkan dan meyakini), Ta'dhzim wal ikhtirôm (sifat mengagunggkan dan memuliakan), Ta'âtsur fì Qolbî̀ (Mengesankan dalam hati), Niŷatul amal wa tablîgh (Niat mengamalkan dan menyampikan).

Membentuk wanita menjadi Da'iyah atau seorang pendakwah wanita, setiap program khurûj fî sabîlillâh setiap wanita di minta untuk menyampaikan kebesaran Allah, mengulang-ulang kebesaran Allah dan tidak mebicarakan masalah keduniaan selama program khurûj fi sabîlillâh. Dengan demikian kebesaran Allah Swt akan masuk kedalam hati karena sering dibicarakan, dan wanita belajar menyampaikan dan menyeru wanita lainnya untuk bersama-sama taat kepada Allah. Bahwasanya Allah Swt adalah sang Khaliq (Penguasa), Allah Swt Raziq (Pemberi Rezeki), Allah Swt Sami' (Maha Mendengar), Allah Swt basyîr (Maha Mendengar), Allah Swt alim (Maha Mengetahui). Setelah di ulang-ulang maka semakin meresap kedalam hati. Selain diminta untuk senantiasa menyampaikan kebesaran Allah, setiap wanita juga diminta untuk saling menasehati satu sama lain jika ada kesalahan atau kekurangan.

Wanita dibentuk menjadi seorang 'abidah (ahli ibadah), dalam program khurûj fî sabîlillâh wanita tinggal di rumah salah seorang anggota jama'ah tabligh dengan persyaratan tidak ada seorang lelaki pun di dalam rumah tesebut dan di perbolehkan untuk balita dan anak-anak tinggal bersama para wanita yang sedang khurûj fî sabîlillâh. Sedangkan lelakinya beri'tikaf di masjid di dekat rumah tempat tinggal wanita (masturoh). Selama berada di rumah tersebut wanita melaksanakan program yang tersusun. Melaksanakan kewajiban sholat, membaca Al-Qur'an, ta'lim wa ta'alum (belajar dan mengajarkan), dzikir, mudzakaroh dan amalanamalan sunnah lainnya.

Jama'ah tabligh melalui metode dakwah khurûj fî sabîlillâh membentuk wanita menjadi Zahidah (Sederhana), peranan ini dilaksanakan untuk memelihara pola fikir seorang wanita yang mayoritas bersifat boros dan mubadzir, dengan meluangkan waktu, harta dan diri, di rumah saudari muslimah yang lain, berbeda keadaan ekonomi, fasilitas, hal ini akan memberikan sifat zuhud dan qonaa'ah.

Terkahir membentuk wanita menjadi khadimah (pelayan) bagi keluarganya. Bentuk ini berguna untuk kembali menata kehidupan para wanita agar bisa sesuai dengan kodranya sebagai wanita, yaitu sebagai khadim (pelayan) bagi suami, anak, dan keluarganya.

Seluruh bentuk tujuan akhir dari gerakan dakwah yang dilakukan oleh Jama'ah Tabligh setelah membentuk seorang wanita menjadi pribadi yang 'alimah, 'abidah, murabbiyah, da'iyah, khadimah dan zahidah. Tahap selanjutnya adalah menerapkan seluruh aspek diatas dalam bentuk pembinaan keluarga muslim dengan cara membentuk kecintaan terhadap ilmu, ketaatan dan ketundukannya kepada Allah dan Rasul-Nya, menjadikan rumah sebagai tempat untuk beribadah, menjaga aurat dan hijab, bergaul, tanggung jawabnya terhadap agama, membentuk pendidikan anak-anak, membentuk sifat zuhud terhadap dunia, membentuknya ketaatanya kepada suami dan adab-adab keseharian seperti adab tidur, makan, 
istinja, berjima', mandi besar, rumah tangga, mencuci, berpakaian, memasak, gadis remaja, berpergian (safar), berdo'a.

\section{Gerakan Dakwah Pengertian}

Gerakan dakwah atau lebih sering dikenal dengan dakwah harakah bermakna dakwah dengan atau melalui sistem pergerakan. Sesuai dengan namanya, aliran dakwah yang satu ini lebih menekankan aspek tindakan (aksi) ketimbang wacana (teoritisasi).11 Menurut Hasan al-Qattany, yang dimaksud dakwah harakah adalah dakwah yang berorientasi pada pengembangan masyarakat Islam, dengan melakukan reformasi total (islah) terhadap seluruh aspek kehidupan social, baik terkait dengan individu (islah al-fard), keluarga (islah alusrah), masyarakat (islah al-mujtama')hingga Negara (islah al-daulah). ${ }^{12}$

Kata Harakah itu sendiri secara harfiah berarti gerak atau gerakan, merupakan lawan dari diam (al-Harakah Dlidl al-Sukun). Dikatakan bergerak, bila seorang berpindah atau mengambil posisi baru. ${ }^{13}$ Dan makna harfiah ini, dapat dipahami dua makna penting kata harakah. Pertama, harakah, menunjuk pada suatu gerakan yang timbul setelah masa atau kondisi vakum. Kedua, harakah menunjuk pada suatu usaha pembaruan untuk membawa masyarakat kepada kehidupan baru yang lebih baik. ${ }^{14}$

Harakah (movement), menurut Kalim Siddiqui, merupakan watak Islam. Dikatakan bahwa Islam (lahir) menjadi suatu gerakan dan akan selalu menjadi grakan. Gerakan Islam bertujuan mendirikan dan melindungi Negara Islam demi kesejahteraan dan kebahagiaan hidup di dunia maupun di akhirat.15 "The Islamic Movement is the struggle of The Muslims to establish, maintain, develop, devend, extend,or re-establish the Islamic state as an instrument to enjoin good and firbid evil for the walfare, and happiness for the mankind in this world and in the hereafter. ",that the while Islamic state coud be lost, the Islamic movement itself was on-going and could no be lost."16

Dalam perkembangannya dakwah harakah dilihat dari segi substansi dan cakupannya, dakwah harakah mengklaim memiliki ruang gerak yang lebih komprehensif dari pada dakwah pengembangan masyarakat. Jika dalam perkembangannya dakwah harakah dalam melihat keterlibatan dan independensi dari unsur politik dan membatasi gerakanya lebih pada ruang lingkup pendidikan dan pembangunan ekonomi, namun dakwah harakah lebih menilai politik sebagai salah satu bagian yang tak terpisahkan dari sistem Islam, karena dakwah tidak bisa dilepaskan dari politik. Dalam pandangan paradigma harakah, Islam itu disimbolkan dengan 3D, din (agama), daulah (negara), dan dunya (dunia). ${ }^{17}$

11 Ilyas Ismail dan Prio Hotman, Filsafat Dakwah : Rekayasa Membangun Agama dan Peradaban Islam, (Jakarta : Prenada Media Group, 2011), Cet. Ke-1, h. 233

12 Hasan Ibn Falah al-Qattany, al-Tariq ila al-Nahdah al-Islamiyyah, (Riyad : Dar al-Hamidi, 1993), h. $1-10$

13 Raghib al-Ashfahani, al-Mufradat fi Gharib al-Qur'an, (Beirut Libanon : Dar al-Ma'rifah, tt.), h. 114. Lihat pula, Ibn Manzhur, Lisan al-Arab, (Beirut: Dar Shadir, 1990), Cet. Ke-1, h. 410-411

14 Ibid, h. 410-411

15 A. Ilyaz Ismail, Paradigma Dakwah Sayyid Quthub : Rekonstruksi Pemikiran Dakwah Harakah, (Jakarta : Permadani, 2006), Cet.Ke-1, h. 12-13

16 Simi Niazi, A New Paradigm in the Making, dalam Kalim Siddiqui (Ed.) Issues in the Islamic Movement 1980-1981 (1400-1401), (London-Toronto-Pretoria : The Open Press Limited, 1982), h. 330-331

17 Ilyas Ismail dan Prio Hotman, Filsafat Dakwah..., Op.Cit., h. 233 
Kemunculan paradigma dakwah bukan hanya berlatar belakang doktrin tersebut ansich, tetapi juga ada factor historis, yakni keterpurukan umat Islam pasca kolonialisme di satu sisi, dan kebangkitan Islam disisi yang lain. ${ }^{18}$

Menurut Ibrahim al-Ja'bari, dakwah harakah sebagai paradigma yang memadukan dimensi pemikiran (konsepsional) dan pergerakan (praktikal), mulai eksis bermunculan di negeri-negeri Islam sejak permulaan abad ke-20 silam dan karenanya model-model dakwah ini banyak diadopsi, misalnya, pergerakan Islam kontemporer Ikhwanul Muslimin di Mesir, Nur Khuluq di Turki, Revolusi Islam di Iran, dan Jama' ati Islam di anak benua India-Pakistan. ${ }^{19}$

Dari segi kebahasaan, kata harakah dapat diartikan sebagai gerak atau gerakan; arti ini dapat kata ini dapat dikontraskan dengan kata al-sukun yang berarti diam (din al-sukun). Dari pemahaman kebahasaan ini, sesuatu yang bergerak itu ditandai jika terdapat perpindahan dari suatu tempat atau itu kondisi ke tempat atau konsidi lainnya. Jika dikaitkan dengan dakwah, maka dakwah yang menghendaki pergerakan dari konsidi vakum sebelumnya, atau menghendaki suatu usaha pembaharuaan untuk membawa masyarakat kepada kehidupan baru yang lebih baik. ${ }^{20}$

Bagi pendukung mazhab ini harakah bukanlah sekedar pandangan atau penafsiran, lebih dari itu, harakah adalah watak dasar bagi suatu gerakan dan akan selalu menjadi gerakan. ${ }^{21}$ Islam tidak dibatasi hanya sebagai agamanya (din), tetapi juga harus diyakini sebagai aturan hidup bermasyarakat (dunya) dan aturan menjalankan pemerintahan (daulah). Paradigma dakwah harakah menegaskan perlunya meyakini Islam sebagai sistem hidup yang komprehensif (manhaj hayah). ${ }^{22}$

\section{Tinjauan Gerakan Dakwah Dari Berbagai Aspek}

Sebagai sistem hidup yang komprehensif (manhaj hayah) menurut Fathi Yakan, Islam tidak boleh dianggap hanya sebagai sistem keyakinan transedental, melainkan suatu sistem yang mengatur seluruh segi kehidupan dari mulai sistem social, ekonomi hingga politik. ${ }^{23}$ Khusus aspek politik, Fathi Yakan membedah karakter harakah Islam dari sistem keyakinan lain. Islam kata Yakan, berbeda dengan agama Kristen misalnya, yang menghendaki pemisahan agama dari Negara. Dalam keyakinan Kristen, agama tidak mencampuri urusan-urusan keagamaan. Kaidah yang amat terkenal terkait dengan pemisahan agama dari Negara ini adalah pernyataan "...berikanlah kaisar milik kaisar dan berikanlah kepada Allah apa yang menjadi milik Allah..."24. Fatih Yakan memaparkan, bahwa kaidah demikian ini tidak dikenal dalam Islam. Kekuasaan Negara, demikian Fatih Yakan

18 Yusuf al-Qardawy, Sahwat al-islamiyah wa Humun al-Watan al-'Arab wa al-Islami, (Kairo : Makhtabah Wahbah, 1997), h. 29

19 Ibrahim Muhammad al-Ja'bari, Gerakan Kebangkitan Islam, alih bahasa Abu Ayyub al-Ansary, (Solo : Duta Rohman, 1996), h. 67-70

${ }^{20}$ Abu Mufdal al-Raghib al-Ashifany, al-Mufradat fi Gharib Al-Qur'an, (Damaskus : Dar Qalam, tt.), Juz 1, h. 226

21 A. Ilyaz Ismail, Paradigma Dakwah Sayyid Quthub Rekonstruksi Pemikiran Dakwah Harakah, (Jakarta : Penamadani, 2006), h. 12

22 Muhammad al-Ghazali, Fi Maukib al-Da'wah, (Kairo : Maktabah Nahdah al-Misr, 2005), h. 163

${ }^{23}$ Fathi Yakan, Kaifa Nad'u ila al-Islam, (Beirut: Muassasah al-Risalah, 1991), h. 89

24 Ibid., h. 97 
menjelaskan, sejatinya ditujukan untuk melindungi agama dan menghadirkan keadilan dalam masyarakat. ${ }^{25}$

Yusuf Qardawy menambahkan, Negara dalam sistem perpolitikan bukanlah sesuatu yang lain dari agama. Agama, begitu Yusuf Qardawy, adalah sebuah sistem ilmiah lengkap (al-Nizâm al-Ilâhi as-Syamîl) yang mencakup pola aturan tentang penyelenggaraan pemerintahan. Konsep pemisahan antara agama dari Negara, lanjut Yusuf Qardawy, selanjutnya bukan lahir dari pemahaman Islam yang benar, tetapi dari pemahaman sekuler yang di impor dari Barat. ${ }^{26}$

Melalui cara pandang ini, aliran dakwah harakah bermaksud untuk menjadikan Islam (hukum Islam) sebagai satu-satunya undang-undang dalam kehidupan, bukan saja kehidupan pribadi (al-ahwal al-syakhsyîyyah), tetapi kehidupan bermasyarakat (al-ahwal al-ijtîma'iyyah), dan kehidupan bernegara (alahwal ad-dauliyyâh). ${ }^{27}$ Untuk tujuan itu secara teoritis paradigma dakwah harakah membuat dikotomi antara sistem Islam dan sistem jahiliyyah. Sistem Islam adalah suatu sistem masyarakat yang dibangun diatas undang-undang ilahiah, yakni syariat Islam. Masyarakat yang dibangun dengan sistem ini disebut masyarakat Islam (al-mujtamấ al-Islamŷ) dan merupakan cita-cita atau tujuan dari diturunkannya Al-Qur'an. Lawannya adalah sistem jahiliah, yakni sistem hidup bermasyarakat yang dibangun atas undang-undang buatan manusia (hukum sekuler) atau (al-qanan al-wad'iyyâhlah al-ardiyyâh), dan masyarakat yang hidup di dalamnya disebut masyarakat jahiliyyah (al-mujtamâ'al-jahily). ${ }^{28}$

Kejahilan menurut pendukung mazhab ini, bukanlah suatu kehidupan manusia, tetapi sebagai kondisi yang dapat hinggap dalam masyarakat mana pun dan kapan pun. Dahulu, dakwah Nabi Muhammad Saw digerakan sebagai upaya untuk mendekontruksi sistem jahiliah Arab dan membangun sistem Islam. Melalui undang-undang Al-Qur'an, dakwah Nabi Muhammad Saw berhasil mentransformasikan masyarakat Arab jahiliah dan membentuk sebuah masyarakat Islam seperti disaksikan sejarah. Bahkan menurut Sayyid Quthub, satu-satunya generasi al-qur'an (Jilun Quranîyyun Farid) yang hingga kini belum ada padananannya, dan sepertinya memang tidak pernah ada, berhasil diwujudkan melalui gerakan dakwah Muhammad Saw.29

Dakwah harakah saat ini perlu dihadirkan demi merekontruksi masyarakat jahiliyah masa sekarang (Jahiliyyat al-Isryin) dan mengulangi kesuksesan dakwah seperti masa Nabi. ${ }^{30}$ Dari sudut pandang metode dakwah, pendekatan yang diterapkan mengikuti cara berfikir mazhab dakwah harakah yang sebetulnya dalam beberapa hal ada kesamaanya dengan mazhab pengembangan masyarakat. Kesamaan itu misalnya dapat ditelaah dari usulan dakwah harakah tentang sosialisasi tauhid sebagai asas pembangunan masyarakat, kebangkitan intelektual dan ekonomi atau kritik keduanya terhadap mazhab dakwah tabligh. Namun, demikian, mazhab dakwah harakah berangkat lebih jauh ketika mengusulkan dakwah yang harus mencakup perbaikan Negara atau pemerintahan. Untuk tujuan

25 Ibid., h. 88

${ }^{26}$ Yusuf Qardawy, Min Figh ad-Daulah fi al-Islam, (Kairo : Dar as-Syuruq, 2001), h. 14

27 Yusuf Qardawy, Syari'at al-Islam as-Salihat li al-Tatbiq fi kulli zaman wa Makan, (Kairo : Dar alSahwah, 1993), h. 89

28 Sayyid Quthub, Nahwa Mujtama' Islamy, (Kairo : Dar al-Syuruq, 1993), h. 64

29 Sayyid Quthub, Maalim fi al-Tariq, (Kairo: Dar al-Syuruq, 1979), h. 13

30 Sayyid Quthub, Tafsir Fi Zilal Al-Qur'an, (Mauqi al-Tafsir), Juz 4, h. 25 
itu, dakwah harakah mengambil jalur pendekatan dakwah massif. Pendekatan dakwah itu misalnya terlihat dari konsep dakwah jihad atau perang suci untuk mewujudkan pemerintahan Islam. ${ }^{31}$

Menurut mazhab ini, pemerintahan Islam bukanlah alternative (pilihan), melainkan imperative (kewajiban). Untuk itu, umat Islam diwajibkan untuk mewujudkan cita-cita tersebut, jika tidak dapat dilakukan dengan perubahan dari dalam secara structural, maka pendekatan dakwah meningkat dalam wujud yang massif, perang suci. Umat muslim, menurut mazhab ini, wajib melawan dan menghancurkan setiap kekuatan yang menghalang-halangi dakwah untuk mewujudkan pemerintahan Islam. Bahkan Sayyid Quthub, salah seorang penggagas mazhab dakwah ini menegaskan, semua musuh Islam, baik dari kelompok Barat maupun golongan elite muslim yang menghalangi terbentuknya pemerintahan Islam dan penerapan syariat Islam, adalah kaum elite yang mesti ditumpas dalam perang suci oleh mereka yang beriman. ${ }^{32}$

Ketegasan ini dimaskudkan untuk membebaskan manusia dari penyembahan sesama manusia atau yang disebut tagût (tirani). Dalam pemerintahan yang menerapkan syariat Islam, manusia akan berdiri sederajat dengan menusia lainnya di hadapan Allah Swt. Kesetaraan atau egalitarianism itu tidak mungkin dapat terwujud kecuali jika Negara menerapkan undang-undang berdasarkan syariat Allah saja. Manusia, menurut cara pandang ini, tidak memiliki wewenang apapun untuk menguasai manusia lainnya. Lebih dari itu, mereka hanya diberi amanat untuk mengurus rakyat dan menciptakan keadilan bernegara dengan perantaraan undang-undang syariat. Sebaliknya, manusia dilarang untuk tunduk pada ketentuan apa pun kecuali ketentuan yang dating dari Allah.

Untuk itu pemimpin Negara tidak berhak membuat ketentuan berdasarkan ketentuan jahiliah, yang bukan berasal dari syariat. Sebaliknya mereka dituntut untuk mengatur rakyatnya berdasarkan undang-undang syariat dan mereka juga memiliki kewajiban untuk tunduk dibawah undang-undang ini. Penyalahan akan prinsip tersebut, akan termasuk dalam sistem jahiliah, dan umat muslim sama-sama memiliki tanggung jawab untuk mengubah sistem ini, dengan jalan damai jika masih bias, atau dengan perang suci jika kendali memang menghendaki demikian. ${ }^{33}$

Untuk mencapai cita-cita, maka pendekatan dakwah mesti dilakukan pertama-tama adalah pembentukan gerakan. Pembentukan gerakan ini dimaksudkan untuk menciptakan pendukung utama atau jama'ah inti. Gerakan ini dibentuk dalam sebuah ikatan solidaritas keimanaan dan memiliki tanggung jawab untuk pengembangan Islam dan lingkungannya, memperluas wilayah dan jaringannya sehingga dakwah Islam dapat menyebar keseluruh penjuru dunia. ${ }^{34}$

Gerakan-gerakan dakwah ini mesti dibina dan dididik dengan tauhid yang mantap, karena mereka itu sejatinya mereka akan dibentuk menjadi agen-agen tauhid diseluruh dunia. Mereka juga dibina (tarbiyyah) dalam satu pelatihan (liqấ) supaya memiliki kualitas ibadah dan akhlak yang baik agar terampil dalam melakukan pengaturan atau pengoraganisasian (tanzim) terhadap pergerakan dakwah. ${ }^{35}$ Kemudian pendekatan harakah dilanjutkan dengan membentuk suatu

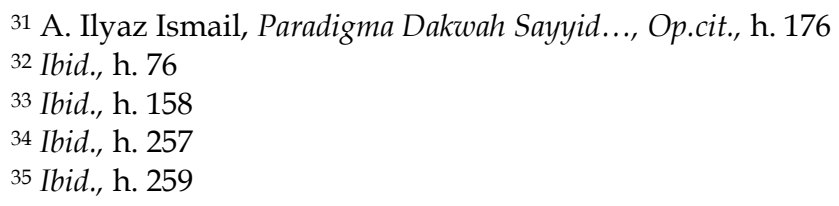


distingtif (mufassalah) antara pergerakan dakwah yang berlandaskan Islam dan pergerakan lain yang berlandaskan sistem jahiliah. Pembedaan ini terbilang sangat urgen demi mencegah terjadinya pencampuradukan antara kedua sistem yang tidak dapat dikompromikan itu. Dalam konteks kehidupan bermasyarakat pemisahan itu dimaksudkan untuk mencegah terjadinya peleburan pemahaman yang merupakan akses kepada distorsi-distorsi atas ajaran dakwah yang benar. ${ }^{36}$

Mazhab dakwah harakah patut mendapat apresiasi terutama ide-idenya yang berhasil mengangkat derajat dan martabat dakwah Islam dari anggapan bahwa dakwah sekedar tabligh. Mazhab dakwah harakah juga layak mendapat apresiasi terutama karena idenya yang mampu untuk menghadirkan pandangan dakwah yang lebih holistis dan komperhensif. Hadirnya mazhab harakah mampu menjadi inspirasi bagi banyak gerakan dakwah lainnya, yang menyandarkan bahwa dakwah sejatinya mesti lebih banyak aspek praktikal melebihi terorientasi. Karena bagaimanapun juga kehadiran dakwah ditujukan untuk melakukan perubahan, sedangkan perubahan ini memerlukan lebih banyak tindakan (lisan al-Hal) melampaui ucapan (lisan al-maqal).

Dari sudut pandang teologis, sebetulnya paradigma harakah ini memiliki kedekatan dengan dakwah salafi atau yang dikenal dengan wahaby. Dalam pemetaan pemikiran pembaruan, dakwah harakah yang dikarsai oleh ulama-ulama negeri pyramid seperti al-Bana, Sayyid Quthub, Fathi Yakan dan kemudian diteruskan oleh Yusuf Qordhowy ini, memiliki corak pemikiran yang cenderung konserfatif-revivalis. Disebut konsefatif karena berusaha untuk melestarikan paham orthodoksi Islam dan bersikap apriori (acuh) bahkan kerap mecurigai usaha-usaha pembaharuan (modernisasi). ${ }^{37}$ Disebut juga revivalis, karena pemikiran yang menjadi ideologi gerakan dakwah ini berusaha menghidupkan tradisi atau nilainilai Islam lama di masa kini dan sangat bersemangat dalam mendakwahkan ide puritanisme. ${ }^{38}$

Sepeninggal syahidnya Sayyid Quthub, Yusuf Qardhawy kemudian menjadi tokoh yang fatwa-fatwanya banyak di adopsi dalam gerakan dakwah harakah. Secara pemikiran, Yusuf Qordhowy dinilai banyak orang cendrung lebih moderat dibanding para pendahulunya, dan dengan kemoderatannya itu ia berhasil mendapatkan banyak simpatisan termasuk gerakan dakwah al-ikhwan al-muslimin. Dengan kemodalannya itu pula, Yusuf Qordhowy mendapatkan kecaman dari gerakan dakwah ultra konservatif yang menganggapnya sebagai ahli fikir yang ingkar sunnah. Terlepas dari pro kontra itu, dari ukuran intelektual muslim seperti Hasan Hanafi dan Muhammad Arkoun, menurut Lutfhi Assakanie, Yusuf Qordhowy tetap dinilai sebagai ulama konservatif dan karena itu, dakwah harakah

36 Ibid., h. 271

37 Modernisasi adalah usaha mendamaikan Islam dengan situasi alam modern. Penegasan ini diperlukan, sebab gerakan-gerakan Islam konservatif juga mengklaim mengadakan pembaruan Islam, namun dengan pengertian yang berbeda. Menurut yang terakhir ini, pembaruaan atau tajdid bukanlah modernisasi, tetapi Islamisasi alam modern, yaitu gerakan menjadikan alam modern ini sesuai dengan syariat Islam. Menurut Luthfi Assyukanie, konsep yang terakhir ini bukan pembaruaan (reformation), tetapi lebih tepat disebut pengulangan (restatement). Lutfhi Assyukanie, Islam Benar Versus Islam Salah, (Jakarta : Kata Kita, 2007), h. 11 2004), h. 205

38 Jhon L, Esposito, Islam The Straight Path, alih bahasa Arif Mafthuhin, (Jakarta : Paramadina, 
yang sekarang ini banyak mengdahapi ide-ide Yusuf Qordhowy menurut banyak penelitian tetap bercorak gerakan konservatif. ${ }^{39}$

Karakter dakwah harakah yang cenderung massif dan eksklusif (terutama karena konsep 'uzlah dan mufassalah), dinilai banyak kalangan sebagai berseberangan dengan nilai-nilai kebijakan lokal (Sophia perennis) dan cenderung idealis. Oleh karena itu, dalam perkembangannya, praktik dakwah harakah lebih sering mengalami benturan-benturan dengan budaya local dan kebijakan penguasa setempat. 40 Pada akhirnya, dan demi kelangsungannya, secara factual, dakwah harakah mau tidak mau mengalami tarik ulur dengan konteks keindonesiaan misalnya, PKS dengan klaimnya sebagai partai dakwah (mazhab harakah), telah beberapa kali melakukan perubahan pendekatan. ${ }^{41}$ Segi kekurangan inilah yang nantinya menjadi kritikan dan disempurnakan oleh mazhab dakwah cultural, yaitu mazhab dakwah yang lebih indigenous dengan pendekatan kebudayaan dan peradabannya. ${ }^{42}$

\section{Karakteristik Gerakan Dakwah}

Menurut Mustafa Masyhur, dakwah harakah mendasarkan diri pada tiga kekuatan sekaligus, yaitu (1) kekuatan aqidah dan iman, (2) kekuatan persatuan dan ikatan kaum muslimin (quwwat at-waddah wa at-tarabbuth) dan (3) kekuatan jihad (quwwat al jihad).43

Menurut Fathi Yakan, ada empat cirri yang sangat menonjol dari dakwah harakah, yaitu (1) murni dan autentik (dzatiyyah), yakni autentik sebagai panggilan Tuhan, (2) mendorong kemajuan (taqaddumiyah), yakni kemajuan yang tetap menjunjung tinggi nilai-nilai moralitas, (3) universal (syamilahi) mencakup semua aspek kehidupan, memadukan tiga sistem hidup (manhaj al hayat) yang terdiri dari tiga D, yaitu Din (agama), Dunya (dunia), dan Daulah (pemerintahan negara) dan (4) menekankan prinsip-prinsip agama yang luhur dan menjauhkan diri dari perbedaan mazhab. ${ }^{4}$

Menurut Sayyid Qutub, seorang aktifis dan arsitek dakah gerakan di Mesir ada tiga ciri dakwah gerakan, yaitu : (1) lebih menekankan pada aksi ketimbang teori, wacana dan retorika, sebagaimana dakwah Nabi yang tidak membangun wacana (la yuqim falsafatan) tetapi membangun ummat (lakin yubni ummah), (2) dakwah gerakan membolehkan penggunaan kekuatan fisik dalam membentuk jihad fisabilillah jika keadaan memaksakan. Jihad diperlukan untuk mengawal dakwah dan membela diri dari gerakan fisik yang menghalangi dakwah, dan (3) dakwah gerakan sangat meniscayakan organisasi dan jaringan (networking), dalam skala nasional, regional, maupun internasional. Menurut Sayyid Qutub, dakwah bukan saja tugas individual, tetapi tugas dan kewajiban kolektif seluruh muslim. Organisasi dakwah gerakan haruslah bersifat terbuka yang dibangun di atas

\footnotetext{
${ }^{39}$ Lutfhi Assakaine, Islam Benar Versus..., Op.cit., h. 179

40 Ilyas Ismail dan Prio Hotman, Filsafat Dakwah..., Op.cit., h. 243

41 Ibid., h. 242

42 Ibid., h. 243

${ }^{43}$ Faizah \& Lalu Muchsin, Psikologi Dakwah, (Jakarta : Kencan, 2006), Edisi Pertama, Cet. Ke-2,

${ }^{44}$ Ibid, h. xvi
} h. xvi

E-Journal : http://journal.iai-agussalimmetro.ac.id/index.php/mauidhohhasanah ISSN : http://issn.pdii.lipi.go.id/issn.cgi?daftar\&1562655370\&1\&\& 
platform akidah tauhid dan ukhuwah Islam tanpa mengenal perbedaan suku, ras, dan warna kulit. 45

1. Da'i Gerakan Dakwah

Suatu pergerakan pasti memerlukan dukungan kader. Kader dakwah gerakan adalah da'i, tetapi da'i dalam paradigma gerakan, yaitu pejuang dakwah (mujahid ad-da'wah). Disini, da'i adalah seorang pejuang dan aktifis pergerakan Islam, yang sudah membekali diri dengan ilmu, wawasan dan ghirah dinnîyah sehingga tabah menghadapi ejekan, siksaan fisik dan bahkan siap menjadi syahid. Semboyan mujahid dakwah adalah Allâh û muqshadunâ (Allah tujuan kita), Al-Qur'an imâmunâ (Al-Qur'an imam kita), wa Sunnah sabîlinâ (sunnah nabi jalan kita), dan al-mautu fí sabîlillâh amanunâ (mati syahid harapan kita). ${ }^{46}$

2. Kepentingan Gerakan Dakwah

Perberlakian dakwah gerakan tidak sepanjang zaman, tetapi hanya jika keadaan memaksa, yaitu (1) ketika dakwah dihambat oleh kekuatan fisik, sehingga sama sekali tidak ada peluang untuk menyebarkan Islam (berdakwah) secara damai, (2) ketika ada kesiapan pada kaum muslimin, kesiapan mental, moral, dan kekuatan, (3) penggunaan kekuatan fisik dalam dakwah gerakan bersifat darurat. Jika keadaan kembali menjadi kondusif untuk berdakwah secara damai, maka penggunaan kekuatan fisik harus dihentikan. ${ }^{4}$

Perbedaan Islam di berbagai belahan bumi berbeda-beda dan untuk mengambil keputusan merespons keadaan diperlukan pemikiran mendalam serta ijtihad yang ikhthiyath (hati-hati) karena rentan terhadap penyusupan pihak lawan, seperti yang dialami oleh Jama'ah Islamiyah yang dipimpin oleh Abu Bakar Ba'asyir dan Habib Riziq, juga lasykar jihad Ja'far Umar, dan lasykar jihad Imran. 48

\title{
Penggerakan Dakwah
}

Adapun pengertian penggerakan dakwah adalah seluruh proses pemberian motivasi kerja kepada para bawahan sedemikian rupa, sehingga mereka mampu bekerja dengan ikhlas demi tercapainya tujuan organisasi dengan efisien dan ekonomis. Motiving secara implicit berarti, bahwa pimpinan organisasi di tengah bawahannya dapat memberikan sebuah bimbingan, intruksi, nasihat, dan koreksijika diperlukan. ${ }^{49}$ Agar fungsi dari penggerakan dakwah ini dapat berjalan secara optimal, maka harus menggunakan teknik-teknik tertentu meliputi:50

1. Memberikan penjelasan secara komprehensif kepada seluruh elemen dakwah yang ada dalam organisasi dakwah.

2. Usahakan agar setiap pelaku dakwah menyadari, memahami, dan menerima baik tujuan yang telah diterapkan.

3. Setiap pelaku dakwah mengerti struktur organisasi yang dibentuk

\author{
45 Ibid., h. xvii \\ 46 Ibid., h. xvii \\ 47 Ibid., h, xvii \\ 48 Ibid., h. xviii \\ ${ }^{49}$ M. Munir \& Wahyu Ilaihi, Manajemen Dakwah, (Jakarta : Kencana, 2009), Cet. Ke-2, h. 139 \\ 50 Ibid, h. 139
}


4. Memperlakukan secara baik bawahan dan memberikan penghargaan yang diiringi dengan bimbingan dan petunjuk untuk semua anggotanya.

Dari semua potensi dan kemampuan ini, maka kegiatan-kegiatan dakwah akan teakomodir sampai kepada sasaran yang telah ditetapkan. Ada beberapa poin dalam proses pergerakan dakwah yang menjadi kunci dari kegiatan dakwah, yaitu : Pemberian motivasi, Bimbingan, Penyelenggaraan komunikasi, dan Pengembangan dan peningkatan pelaksana. ${ }^{51}$

\section{Strategi Gerakan Dakwah}

Strategi dakwah adalah metode siasat, taktik atau manuver yang dipergunakan dalam aktivitas dakwah. ${ }^{52}$ Asmuni menambahkan, strategi dakwah yang dipergunakan dalam usaha dakwah harus memperhatikan beberapa hal, antara lain:

1. Azas filosofi, yaitu azas yang membicarakan tentang hal-hal yang erat hubungannya dengan tujuan yang hendak dicapai dalam proses dakwah;

2. Azas psikologi, yaitu azas yang membahas tentang masalah yang erat hubungannya dengan kejiwaan manusia. Seorang da'i adalah manusia, begitu juga sasaran atau objek dakwah yang memiliki karakter kejiwaan yang unik, sehingga ketika terdapat hal-hal yang masih asing pada diri mad'u tidak diasumsikan sebagai pemberontakan atau distorsi terhadap ajakan;

3. Azas sosiologi, yaitu azas yang membahas masalah-masalah yang berkaitan dengan situasi dan kondisi sasaran dakwah, misalnya politik masyarakat setempat, mayoritas agama di daerah setempat, filosofi sasaran dakwah, sosio-kultur dan lain sebagainya, yang sepenuhnya diarahkan pada persaudaraan yang kokoh, sehingga tidak ada sekat diantara elemen dakwah, baik kepada objek (mad'u) maupun kepada sesama subjek (pelaku dakwah). Dalam mencoba memahami keberagamaan masyarakat, antara konsepsi psikologi, sosiologi dan religiusitas hendaknya tidak dipisahkan secara ketat, sebab jika terjadi akan menghasilkan kesimpulan yang fatal. 53

4. Azas kemampuan dan keahlian (achievement and profesional), yaitu azas yang lebih menekankan pada kemampuan dan profesionalisme subjek dakwah dalam menjalankan misinya. Latar belakang subjek dakwah akan dijadikan ukuran kepercayaan mad'u;

5. Azas efektifitas dan efisiensi, yaitu azas yang menekankan usaha melaksanakan kegiatan dengan semaksimal mungkin sesuai dengan planning yang telah ditetapkan sebelumnya. ${ }^{54}$

Seluruh azas yang dijelaskan di atas termuat dalam metode dakwah yang harus dipahami oleh pelaku dakwah. Dimana Istilah metode atau methodos (Yunani)

51 Abdul Rosyad Shaleh, Manajemen Dakwah Islam, (Jakarta : Bulan Bintang, 1993), Cet. Ke-3, h.

112

52 Asmuni Syukir, Dasar-Dasar Strategi Dakwah Islam (Surabaya: Al-Ikhlas, 1983), h. 32-33.

53 Ahmad Anas, Paradigma Dakwah Kontemporer, Aplikasi dan Praktisi Dakwah sebagai Solusi Problematikan Kekinian (Semarang: Pustaka Rizki Putra, 2006), Cet. Ke-1, h. 184.

54 Sutikno, http://sutiknotaliabo.blogspot.co.id/2013/05/strategi-dakwah.html, diakses pada tanggal 17 April 2019, pukul 12.00 WIB 
diartikan sebagai rangkaian, sistematisasi dan rujukan tata cara yang sudah dibina berdasarkan rencana yang matang, pasti dan logis. ${ }^{55}$

Strategi pada hakekatnya adalah perencanaan (planning) dan management untuk mencapai suatu tujuan. Tetapi untuk mencpai tujuan tersebut, strategi tidak hanya berfungsi sebagai peta jalan yang hanya menunjukkan arah saja, melainkan harus menunjukkan bagaimana tekhnik (cara) operasionalnya. Dengan demikian strategi dakwah merupakan perpaduan dari perencanaan (planning) dan management dakwah untuk mencapai suatu tujuan. Di dalam mencapai tujuan tersebut strategi dakwah harus dapat menunjukkan bagaimana operasionalnya secara tekhnik (taktik) harus dilakukan, dalam arti kat bahwa pendekatan (approach) bias berbeda sewaktu-waktu bergantung pada situasi dan kondisi.

Untuk tercapainya strategi dakwah, maka segala sesuatunya harus dipertautkan dengan komponen-komponen yang merupakan jawaban terhadap pertanyaan dalam rumus Lasswell, yaitu:

1. Who? (Siapa da'i atau penyampai pesan dakwahnya?)

2. Says What? (Pesan apa yang disampaikan?)

3. In Which Channel? (Media apa yang digunakan?)

4. To Whom? (Siapa Mad'unya atau pendengarnya?)

5. With what Effect? (Efek apa yang diharapkan?) Pertanyaan "efek apa yang diharapkan" secara emplisit mengandung pertanyaan lain yang perlu dijawab dengan seksama.

6. When (Kapan dilaksanakannya?)

7. How (Bagaimana melaksanakannya?)

8. Why (Mengapa dilaksanakan demikian?) Tambahan pertanyaan tersebut dalam strategi dakwah sangat penting, karena pendekatan (approach) terhadap efek yang diharapkan dari suatu kegiatan dakwah bisa berjenisjenis, yakni :

1) Menyebarkan Informasi

2) Melakukan Persuasi

3) Melaksanakan Instruksi.

\section{Pentingnya Strategi Gerakan Dakwah}

Pentingnya strategi gerakan dakwah adalah untuk mencapai tujuan, sedangkan pentingnya suatu tujuan adalah untuk mendapatkan hasil yang diinginkan. Fokus perhatian dari ahli dakwah memang penting untuk ditujukan kepada strategi gerakan dakwah, karena berhasil tidaknya kegiatan dakwah secara efektif banyak ditentukan oleh strategi gerakan dakwah itu sendiri. Dengan demikian strategi gerakan dakwah, baik secara makro maupun secar mikro mempunyai funsi ganda, yaitu :

1. Menyebarluaskan pesan-pesan dakwah yang bersifat informatif, persuasif dan instruktif secara sistematik kepada sasaran untuk memperoleh hasil optimal.

2. Menjembatani "Cultur Gap" akibat kemudahan diperolehnya dan kemudahan dioperasionalkannya media yang begitu ampuh, yang jika dibiarkan akan merusak nilaii-nilai dan norma-norma agama maupun

55 Onong Uchjana Efendi, Ilmu, Teori dan Filsafat Komunikasi (Bandung: PT. Citra Aditya Bakti, 2003), h. 56. 
budaya. Bahasan ini sifatnya sederhana saja, meskipun demikian diharapkan dapat menggugah perhatian para ahli dakwah dan para calon pendakwah yang sedang atau akan bergerak dalam kegiatan dakwah secara makro, untuk memperdalaminya. Jika kita sudah tau dan memahami sifat-sifat mad'u, dan tahu pula efek apa yang kita kehendaki dari mereka, memilih cara mana yang kita ambil untuk berdakwah sangatlah penting, karena ini ada kitannya dengan media yang harus kita gunakan.

3. Cara bagaimana kita menyampaikan pesan dakwah tersebut, kita bias mengambil salah satu dari dua tatanan di bawah ini :

a. Dakwah secara tatap muka (face to face)

1) Dipergunakan apabila kita mengharapkan efek perubahan tingkah laku (behavior change) dari mad'u.

2) Sewaktu menyampaikan memerlukan umpan balik langsung (immediate feedback).

3) Dapat saling melihat secara langsung dan bisa mengetahui apakah mad'u memperhatikan kita dan mengerti apa yang kita sampaikan. Sehingga umpan balik tetap menyenangkan kita.

4) Kelemahannya mad'u yang dapat diubah tingkah lakunya relative, sejauh bisa berdialog dengannya.

b. Dakwah melalui media

1) Pada umumnya banyak digunakan untuk dakwah informatif.

2) Tidak begitu ampuh untuk mengubah tingkah laku.

3) Kelemhannya tidak persuasif.

4) Kelebihannya dapat mencapai mad'u dalam jumlah yang besar.

\section{Peranan Da'i Dalam Strategi Gerakan Dakwah}

Dalam strategi gerakan dakwah peranan dakwah sangatlah penting. Strategi gerakan dakwah harus luwes sedemikian rupa sehingga da'i sebagai pelaksana dapat segera mengadakan perubahan apabila ada suatu faktor yang mempengaruhi. Suatu pengaruh yang menghambat proses dakwah bisa datang sewaktu-waktu, lebih-lebih jika proses dakwah berlangsung melalui media. Menurut konsep A. A. Prosedure, bahwa dalam melancarkan komunikasi lebih baik mempergunakan pendekatan, apa yang disebut A. A. Proceedure atau From Attention to Action Procedure yang di singkat AIDDA. Lengkapnya adalah sebagai berikut: A Attention (Perhatian), I Interest (Minat), D Desire (Hasrat), D Decision (keputusan), A Action (Kegiatan). Maknanya :

1. Proses pentahapannya dimulai dengan membangkitkan perhatian (attention). Dalam hal ini pada diri seorang da'i harus menimbulkan daya tarik (source attactiveness).

2. Sikap da'i berusaha menciptakan kesamaan atau menyamakan diri dengan mad'u sehingga menimbulkan simpati mad'u pada da'i.

3. Dalam membangkitkan perhatian hindarkan kemunculan himbauan (appeal) yang negative sehingga menumbuhkan kegelisahan dan rasa takut.

4. Apabila perhatian mad'u telah terbangkitkan, hendaknya disusul dengan upaya menumbuhkan minat (interest) yang merupakan derajat lebih tinggi dari perhatian. 
5. Minat adalah kelanjutan dari perhatian yang merupakan titik tolak bagi timbulnya hasrat (desire) untuk melakukan suatu kegiatan yang diharapkan mad'u.

6. Hasrat saja pada diri mad'u belum berarti apa-apa, sebab harus dilanjutkan dengan keputusan (decission), yakni keputusan untuk melakukan kegiatan (action) sebagaimana diharapkan da'i.

\section{Tujuan Strategi Gerakan Dakwah}

Dengan strategi gerakan dakwah seorang da'i harus berfikir secara konseptual dan bertindak secara sistematik. Sebab komunikasi tersebut bersifat paradigmatik. Paradigma adalah pola yang mencakup sejumlah komponen yang terkorelasikan secara fungsional untuk mencapai suatu tujuan. Suatu paradigma mengandung tujuan. Dan tujuan pada paradigma tesebut, yakni mengubah sikap, opini atau pandangan dan perilaku". (to change the attitude, opinion and behavior), sehingga timbul pada diri mad'u efek afektif, efek kognitif, dan efek konatif atau behavioral. Diantaranya :56

1. Proses Dakwah

Dalam menyusun strategi dakwah harus menghayati proses komunikasi yang akan dilancarkan. Proses dakwah harus berlangsung secara "berputar"(circular), tidak "melurus" (linear). Maksudnya, pesan yang sampai kepada mad'u efeknya dalam bentuk tanggapan mengarus menjadi umpan balik. Mengevaluasi efek dari umpan balik terseut negative atau positif.

2. Da'i

Mendalami pengetahuan Alqur'an dan Hadits, pengetahuan huukum Islam lainnya. Sejarah nabi, ibadah, muamalah, akhlak, dan pengetahuan Islam lainnya. Menggabungkan pengetahuan lama dan modern. Menguasai bahasa setempat. Mengetahui cara berdakwah, system pendidikan dan pengajaran, mengawasi dan mengarahkan. Berakhlak mulia. Para da'i harus bijaksana, dan berpenampilan yang baik. Para da'i haus pandai memilih judul, dan menjauhkan yang membawa kepada keraguan. Da'i adalah imam dan pemimpin.

3. Pesan Dakwah

Sistematis dan objektif. Bahasanya ringan sesuai dengan situasi dan kondisi. Tidak harus panjang lebar. Pesan dakwah sesuai dengan Alqur'an dan Hadits. Meyakinkan tidak meragukan. Isinya menggambarkan tema pesan secara menyeluruh.

4. Media Dakwah

Radio, Mimbar, Televisi, Dan Publikasi lainnya, Film Teater, Majalah, Reklame, Surat Kabar

5. Mad'u

Komponen yang paling banyak meminta perhatian. Sifatnya, heterogen dan kompleks. Selektif dan kritis memperhatikan suatu pesan dakwah, khususnya jika berkaitan dengan kepentingannya.

56 Husin Ismail, http:/ / uchinfamiliar.blogspot.co.id/2009/04/strategi-dakwah-melaksanakaninstruksi.html, diakses pada tanggal 17 April 2019, pukul 11.31 WIB 


\section{Perkembangan Strategi Gerakan Dakwah}

Kurun waktu perjuangan Rasulullah Saw. telah kita lewati sejak 14 abad yang lalu. Sebuah perjuangan dan pengorbanan dalam menjalankan misi yang diembankan keatas pundak beliau untuk berdakwah menyeru dan mengajak seluruh manusia agar meng-esakan Allah SWT sebagai Tuhan yang sebenar untuk disembah dan mengajak agar manusia mengakui beliau adalah salah seorang utusan Allah. Secara singkat dakwah Rasulullah boleh dikatakan sangat berhasil. Melanjutkan misi dakwah Rasulullah tersebut juga mempetahankan dan melestarikan hasil jerih payah yang telah beliau tinggalkan, yaitu ajaran Islam.

Konteks strategi gerakan dakwah yang dulu dan sekarang tentu berbeda karena memang situasi dan tantangannya berbeda pula. Namun tujuan dan sasaran dakwah haruslah tetap sama yaitu tauhidillah. Dulu Rasulullah Saw. berdakwah dalam situasi dan kondisi dimana kebanyakan manusia benar-benar tidak mengenal Allah Swt. dan sama sekali tidak tahu tentang norma-norma akhlak yang terpuji. Yang ada hanya kekejaman, kekerasan tak berprikemanusiaan, seperti merampas hak-hak orang lain, mengubur hidup-hidup anak perempuan dan kebiasaan mabuk-mabukan.

Semua itu bukanlah hal yang asing bagi masyarakat dakwah Rasulullah saat itu. Caci maki dan penyiksaan bahkan pengucilan dilancarkan dengan gencarnya oleh kaum kafir Quaraisy tehadap pengikut Nabi Muhammad Saw. Mereka melakukan hal itu semua agar Gerakan Dakwah Islamiyah menjadi sempit sekaligus agar bisa menjadi propaganda kepada orang-orang bahwa siapa yang memilih beriman berarti ia memilih penderitaan. Perubahan zaman tentu diiringi dengan datangnya tantangan dan problematika yang lebih banyak, sulit menghadapinya, baik masa sekarang maupun di masa yang akan datang.

Muhammad Qutb dalam bukunya yang berjudul "Jahiliyah Abad XX" menyinggung gejala-gejala kemunduran dunia keabad-abad sebelumnya 'Return to back future'. Kemunduran yang beliau maksudkan adalah seolah-olah kemajuan peradaban yang pesat yang terjadi di saat ini tak ada bedanya dengan peradaban Yunani dan Romawi pada masa lampau. Dimana kemajuan ekonomi, politik dan ilmu pengetahuannya mampu mendominasi sebagian besar pelosok-pelosok dunia, termasuk Jazirah Arab.

Tapi mengapa masa tersebut disebut masa kebodohan (jahiliyah). Jawabannya adalah karena kemajuan yang mereka capai dalam segi material tidaklah begitu bernilai dibanding kemajuan dalam segi spiritual. Itu karena mereka mempertuhankan kemajuan tersebut sementara jiwa mereka kosong dari keimanan kepada Allah Swt. Dan malah justru kemajuan tersebut membuat mereka menjadi tidak percaya dengan adanya hari akhirat. Kejahiliyahan spiritual juga berbentuk penafian terhadap hukum Allah, sebagaimana yang difirmankan oleh Allah Swt:

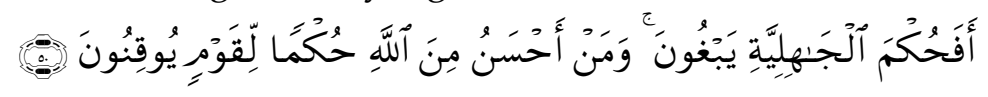

Artinya : "Apakah mereka mengehendaki hukum jahiliyah? Dan hukum siapakah yang lebih baik daripada hukum Allah bagi orang-orang yang yakin". (QS. Al-Ma'idah: 50). 57

Dalam pembahasan strategi gerakan dakwah di abad modern, kita tak bisa melepaskan diri dari upaya memahami situasi yang ada, yaitu bahwa tantangan

57 Departemen Agama RI, Al-Qur'an dan Terjemah, (Jakarta : Maghafirah Pustaka, 2006), h. 120 
Dakwah Islamiyah saat ini adalah jahiliyah modern yang memiliki gambaran sebagai berikut: 58

Tidak beriman kepada Allah SWT, atau tidak adanya keyakinan mutlak atas ketuhanan Allah dan keyakinan bahwa Dia-lah satu-satunya yang berhak atas ketentuan hukum.

1. Adanya pemerintahan thagut di muka bumi yang memalingkan manusia dari syari' at Allah Swt.

2. Kerusakan di bidang pemikiran seperti paham sekularisme, komunisme dan sebagainya.

3. Kerusakan di bidang moral.

4. Kerusakan di bidang politk, ekonomi sosial, seni budaya dan lain-lain.

Semua fenomena diatas sangat memerlukan solusi yang tepat dan benar. Memahami objek dakwah sangat menetukan metode penyampaian yang akan dipergunakan. Namun strategi dakwah dalam menghadapi tantangan seperti yang tersebut diatas secara umum antara lain:

1. Memahami betul manhaj dakwah Rasulullah Saw. mentauladani Rasulullah dari segi kepribadian, sifat dan sikap beliau dalam berdakwah.

2. Jadilah qudwah hasanah (contoh yang baik) bagi semua orang. Karena hal ini membuat dakwah kita lebih mudah diterima dan berkesan kuat di hati orang lain.

3. Mengantisipasi segala bentuk tantangan dakwah dengan konsekuensi harus mangamalkan ajaran agama Islam dalam kehidupan sehari-hari.

4. Berusaha memurnikan kembali pemahaman terhadap Islam yang diselewengkan serta menandingi arus gerakan westernisasi dan kristenisasi dengan memperbanyak media dakwah yang memungkinkan seperti mempergunakan televisi, radio, media cetak dan sebagainya.

Dakwah butuh strategi, bukan sekedar asal-asalan dalam berdakwah. Strategi ini bisa dipraktikkan dalam ruang lingkup kecil di tengah-tengah keluarga, kerabat, hingga masyarakat secara umum. Menurut Syaikhul Islam Ibnu Taimiyah yang dihimpun oleh Muhammad Abduh Tuaskial, ada beberapa strategi gerakan dakwah, diantaranya :59

1. Dakwah yang pertama adalah dakwah tauhid dan pembinaan akidah.

2. Prioritaskan materi dakwah yang lebih penting: dakwah pada tauhid, baru dakwah pada amalan yang lebih penting, dan tidak mesti langsung pada perkara parsial (juz'îyât).

3. Dakwah mesti dengan cara yang tepat dengan memperhatikan kondisi masyarakat.

4. Dakwah pada dalil dari Al-Qur'an dan As-Sunnah, jangan sampai dakwah tanpa dalil, tanpa mengikuti tuntunan.

5. Dakwah itu mengajak orang melakukan perintah dan menjauhi larangan (amar makruf nahi mungkar).

6. Berdakwah sesuai kemampuan.

58 Khairy Abusyairi, http://kmkmmedia.blogspot.co.id/2013/03/strategi-dakwah-islamiyahdi-jaman.html, di akses pada tanggal 17 April 2019, pukul 10.02 WIB

59 Syaikhul Islam Ibnu Taimiyah, Qawa'id wa Dhawabith Figh Ad-Da'wah 'Inda, (Kairo : Dar Ibnul Jauzi, tt.t, 2010), Cet. Ke-2 
7. Kemungkaran yang nampak wajib diingkari.

8. Mengingkari dalam hati lalu lisan didahulukan daripada mengingkari dengan tangan.

9. Mengingkari kemungkaran hanya boleh dengan hujjah (dalil) yang jelas.

10. Tidak boleh mengingkari kemungkaran dengan hal yang lebih mungkar.

11. Siapa yang menghadiri suatu acara kemungkaran dengan pilihan hatinya, maka ia dihukumi seperti melakukan kemungkaran tersebut.

12. Melarang sesuatu kemungkaran hendaklah mengarahkan juga pada hal yang manfaat lainnya, bukan sekedar melarang.

13. Hendaklah yang berdakwah menyelamatkan bahaya dirinya sebelum bahaya pada orang lain. ${ }^{6}$

\section{Wanita Jamaah Tabligh}

Allah Swt telah menyempurnakan nikmat-nikmat-Nya yang besar kepada hamba-hamba-Nya dan nikmat termanis setelah iman adalah keharmonisan keluarga. Baiti jannati (rumahku surgaku) merupakan term yang sering dipakai dalam menempuh kehidupan berkeluarga dan dalam pembinaan keluarga muslim. ${ }^{61}$ Seorang Ibu ibarat guru dalam keluarga. Ibu yang mengurus semua urusan rumah tangga. Sementara ayah adalah seorang mujahid dan pencari rezki pada keluarga. ${ }^{62}$ Dalam menanggapi berbagai perubahan zaman dan perkembangan teknologi menyebabkan kemajuan di berbagai bidang. Seorang muslimah dalam sejati yang tidak tercemari dengan berbagai akulturasi dari berbagai budaya yang ada. Muslimah sejati adalah wanita yang meyakini Allah Swt sebagai Rabb-Nya, Muhammad Saw sebagai Nabinya, dan Islam sebagai agamanya. Apabila diuraikan lebih spesifik lagi adalah sebagai berikut ${ }^{63}$ :

1. Pertama, Muslimah sejati ialah wanita yang selalu bersemangat menuntu ilmu, semangat dalam mengamalkan ilmunya, dan semangat dalam mengajak orang lain agar mengamalkan ilmunya, sehingga terlihat pada ucapannya, amalannya, dan sikapnya. ${ }^{64}$

2. Kedua, muslimah sejati ialah wanita yang memiliki ketaqwaan, kekhusyu'an, selalu beribadah, dan selalu manjaga kewajibankewajibannya. Selalu istiqomah dalam amal-amal shalihnya, menjauhi perkara-perkara yang diharamkan-Nya, dan selalu waspada terhadap yang dilarang-Nya semata-mata karena takut kepada kemurkaan Allah dan takut akan pedihnya adzab Allah. 65

3. Ketiga, muslimah sejati adalah wanita yang sangat mencintai Allah Swt dan Rasul-Nya serta mentaati setiap perintah Allah dan Rasul-Nya. Dia rela mengorbankan dirinya, hartanya, dan anak-anaknya serta apa saja

60 Muhammad Abduh Tuaskial, https://rumaysho.com/12184-strategi-dakwah-1.html, diakses pada tanggal 17 April 2019, pukul 11.43 WIB

61 Maulana Muhammad Ubaidillah, Keutamaan Masturah, Usaha Dakwah di Kalangan Wanita Menurut Petunjuk Sunnah, (Bandung : Pustaka Ramadhan, 2010), Jilid, Cet. Ke-1, h. iii

${ }^{62}$ Ibid, h. iii

${ }^{63}$ Op.Cit., Musthafa Sayani, Kemulian Wanita Shalihah..., h. 4

${ }^{64}$ Musthafa Sayani, Kemulian Wanita Shalihah..., Ibid., h. 4

${ }^{65}$ Lo.Cit 
yang dimilikinya demi menolong agama Allah dan Rasul-Nya agar tegak di muka Bumi. 66

4. Keempat, muslimah sejati ialah wanita yang selalu mendidik anakanaknya agar menaati Allah Swt dan Rasul-Nya, mengajarkan kepada mereka Aqidah (keimanan) yang benar, menamkan ke dalam jiwa mereka kecintaan kepada Allah dan Rasul-Nya, serta menjauhkan mereka dari perbuatan-perbuatan maksiat dan akhlak-akhlak tercela. ${ }^{67}$

5. Kelima, muslimah sejati ialah wanita yang selalu teguh bagaikan gunung dalam menghadapi berbagai ujian dan kesusahan dalam kehidupan dunia. Tidak pernah goyah hatinya katika menghadapi berbagai kesusahan dan kesulitan dunia, dan selalu zuhud terhadap dunia. Keimanan tertanam di dalam hatinya, sehingga selalu mengharapkan pahala dari Allah atas setiap musibah yang menimpanya. 68

6. Keenam, muslimah sejati ialah wanita yang selalu mentaati suaminya. Dia selalu bersikap lembut dan kasih sayang kepada suaminya, mengajaknya kepada hal-hal yang baik, dan selalu melakukan hal-hal yang menyenangkan suaminya. Selalu menjadi berbaikti kepada suaminya, menjadi patner dan pembantu suaminya dalam pengamalan dan perjuangan agama. ${ }^{69}$

7. Ketujuh, muslimah sejati ialah wanita yang jika suami memandangnya, maka dia dapat menyenangkannya dengan keindahan kata-kata dan senyumannya. Jika suami menyuruhnya maka mentaatinya, dan jika suami sedang pergi maka dapat menjaga dirinya, harta suaminya dan anak-anaknya. ${ }^{70}$

Dari berbagai keterangan diatas mengenai siapa sebenarnya seorang muslimah itu, maka dalam gerakan dakwah yang di lakukan ileh Jama'ah Tabligh terhadap wanita dalam pembinaan keluarga muslim adalah dengan mengajak wanita yang sudah menjadi mahram hakikinya (isteri) untuk keluar di jalan Allah. Tujuan wanita diajak untuk keluar di jalan Allah (khuruj fii sabilillah) adalah ${ }^{71}$ :

1. Menjaga Shalat lima waktu, dengan khusyu (konsentrasi batin) dan khudu' (merendahkan diri dihadapan Allah). Maksudnya, wanita hendaknya mendirikan shalat pada awal waktu, di rumah dan berjamaah.

2. Menghidupkan ta'lim wa ta'lum. Walaupun di rumah tetap harus menghidupkan ta'lim bersama keluarga.

3. Mengerjakan dzikir pagi dan petang, dan membaca Al-qur'an. Sebaiknya wanita menghiasi dirinya dengan memperbanyak dzikir dan membaca Al-Qur'an.

4. Mendidik anak secara Islami. Para ibu hendaknya mendidik anakanaknya dengan cara Rasulullah Saw.

5. Menjaga hijab dan hidup sederhana. Maksudnya, apabila berpergian hendaknya selalu menjaga hijab dan di dampingi mahramnya. Dalam

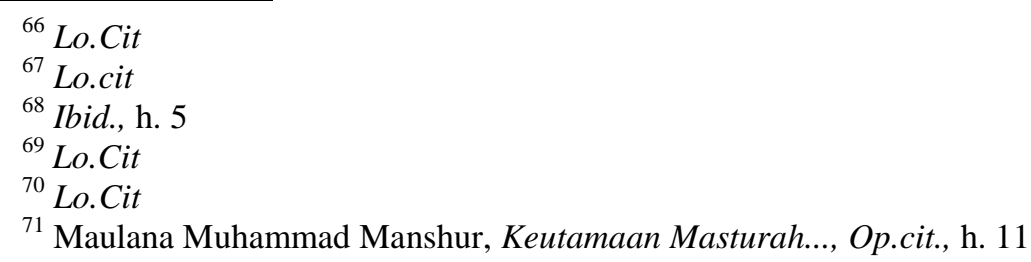


kehidupan sehari-hari hendaknya sederhana, jangan berfoya-foya atau boros.

6. Menganjurkan mahram atau suaminya untuk khuruj fii sabilillah. Jika ada keluarga atau teman wanita yang berkunjung ke rumahnya untuk suatu keperluan, maka dangan kasih sayang, cinta, mahabbah dan hikmah mengarahkan mereka untuk mengamalkan agama, supaya membuat ta'lim di rumah dan mendorong suami atau lelaki untuk khuruj fii sabilillah

Gerakan dakwah Jama'ah Tabligh di kalangan wanita dengan metode khuruj fii sabilillah dengan tertib waktu sebagai berikut ${ }^{72}$ :

1. Jama'ah masturah tiga hari : lelaki pernah khuruj selama tiga hari, wanita pernah hadir dalam ijtima' atau ta'lim masturah. Amir jama'ah masturah tiga hari : pernah khuruj selama 40 hari dan pernah menjadi amir.

2. Jama'ah masturah 10-15 hari : pasangan suami isteri tersebut pernah khuruj masturah tiga hari minimal sebanyak tiga kali. Amir jama'ah 10-15 hari : pernah khuruj 40 hari dan pengalaman khuruj masturah selama 1015 hari.

3. Jama'ah masturah 40 hari dalam negeri dan negara tetangga : pernah khuruj empat bulan, khuruj masturah 15 hari atau lima kali khuruj masturah 3 hari dan di periksa (di-tafakud) oleh syura Indonesia.

4. Jama'ah masturah dua bulan ke India, Pakistan : pernah khuru masturah 15 hari atau 40 hari, di periksa oleh syura Indonesia, dan mendaptkan persetujuan syura Nizamuddin (India).

Khuruj dilakukan dengan mahram hakiki, bagi jama'ah maturah tiga hari adalah isteri, anak wanita, dan saudara wanita, sedangkan untuk Jama'ah masturah lebih dari tiga hari, mahram haqiqinya hanyalah isteri. ${ }^{73}$

Seluruh tujuan diatas adalah salah satu bentuk langkah konkret yang dilakukan oleh Jama'ah Tabligh di kalangan wanita dalam Pembinaan Keluarga. Target usaha masturah secara umumnya adalah agar para wanita dapat menghidupkan agama secara sempurna di dalam rumah dan mendorong para lelaki mahramnya agar dapat menghidupkan agama secara sempurna di luar rumah. Sedangkan target khusus nya adalah ${ }^{74}$ :

1. Menjadi da'iyah. Agar para wanita menjadi da'iyah dan merasa turut bertanggung jawab atas tegaknya agama secara sempurna di seluruh alam, meneruskan kerja Nabi Saw yaitu mengajak manusia kepada Allah.

2. Menjadi 'abidah. Agar para wanita menyibukkan dirinya dengan beribadah di dalam rumahnya, berkeingingan kuat untuk taat kepada Allah dan Rasul-Nya dan menjadikan rumahnya seperti masjid.

3. Menjadi 'alimah. Agar para wanita bergairah kepada ilmu dan menghidupkan suasana belajar dan mengajr di dalam rumah ( $\mathrm{ta}^{\prime} \mathrm{lim}$ wa ta'alum ), sehingga tidak ada kejahilan agama di dalam rumah orangorang Islam.

4. Menjadi murabbiyah. Agar seorang wanita berperan menjadi madrasatul ula (sekolah pertama) bagi ahli keluarga, menjadi sosok pendidik bagi

\footnotetext{
${ }^{72}$ Maulana Muhammad Manshur, Keutamaan Masturah..., Ibid., h. 12

${ }^{73}$ Ibid., h. 12

${ }^{74}$ Ibid., h. 17
}

E-Journal : http://journal.iai-agussalimmetro.ac.id/index.php/mauidhohhasanah ISSN : http://issn.pdii.lipi.go.id/issn.cgi?daftar\&1562655370\&1\&\& 
anak-anaknya di dalam rumah, sehingga lahir dari keluarga muslim anak-anak yang shalih-shalihah, hafidz-hafidzah dan alim-alimah.

5. Menjadi khadimah. Agar wanita dapat melayani suami dan ahli keluarga dengan sebaik-baiknya, senantiasa menunaikan hak orang lain sehingga timbul kasih sayang dan akhlak yang agung pada penghuni Al-qur'an.

6. Menjadi zahidah. Agar para wanita bisa menyederhanakan keperluan hidupnya dan mengarahkan kesibukannya kepada kesibukan agama.

Diantara target umum dan khusus gerakan dakwah Jama'ah Tabligh di kalangan wanita (masturah) dalam pembinaan keluarga muslim, adapun materi dakwah (maddah) yang disampaikan selama program khuruj adalah sebagai berikut:

1. Dalam membentuk muslimah yang 'alimah meteri dakwah yang disampaikan ketika khuruj yaitu :

a. Kepentingan menuntut ilmu agama,

b. Tujuan dan niat menuntu ilmu agama,

c. Keutamaan seorang yang berilmu ('alimah) dan keutamaan menuntut ilmu agama,

d. Ilmu yang wajib dipelajari seorang muslimah, dan

e. Adab-adab muslimah dalam menuntut ilmu.

1) Taqwa,

2) Menuntut ilmu dari mahramnya,

3) Menggunakan hijab atau penghalang dengan yang bukan mahramnya, dan berniat untuk mengamalkan dan menyampaikan.

2. Dalam membentuk muslimah yang 'abidah, maddah yang digunakan adalah :

a. Kewajiban menaati seluruh perintah Allah dan Rasul-Nya,

b. Rumah adalah tempat terbaik bagi muslimah untuk beribadah dan mendekatkan diri kepada Allah Swt.

1) Menjaga shalat lima waktu

2) Kepentingan menjaga shalat lima waktu

3) Tertib shalat berjama'ah bagi muslimah

4) Menjaga ibadah shaum

a) Perintah dan keutamaan shaum ramadhan

b) Beberapa ketentuan shaum bagi muslimah

5) Menjaga tilawah Al-Qur'an

6) Menjaga dzikir tasbihat pagi dan petang

7) Menjaga shalat-shalat sunnah dan nafil (tambahan)

8) Menjaga adab-adab sunnah dalam melakukan aktifitas hidup sehari-hari.

c. Menjaga aurat dan hijab

1) Pengertian aurat

2) Kewajiban menutup aurat

3) Perintah memakai jilbab/hijab

4) Perbedaan antara jilbab/hijab dan satr (penutup aurat).

5) Pergaulan muslimah sejati

6) Penjelasan tentang mahram dan bukan mahram

7) Etika pergaulan muslimah 
d. Kisah-kisah mengenai ketaatan kaum wanita kepada perintah Allah dan Rasul-Nya

1) Pernikahan Zainab r.ha dengan Zaid bin Haritsah ra.

2) Kisah Zulaibib ra. melamar soerang wanita Anshar

\section{Proses Pembinaan Keluarga Jama'ah Tabligh}

Dalam membentuk da'iyah, muslimah yang memiliki cinta kepada Allah dan Rasul-Nya serta tanggung jawabnya terhadap agama Allah :

a. Mencintai Allah dan Rasul-Nya lebih dari segalanya

b. Tanggung jawab seorang muslimah terhadap agama.

a. Kepentingan dakwah bagi muslimah

b. Kewajiban dakwah dan amar ma'ruf nahi mungkar bagi muslimah

c. Keutamaan dakwah dan amar ma'ruf nahi mungkar

d. Tujuan diadakannya dakwah

e. Sasaran dakwah seorang da'iyah

f. Adab-adab dalam melaksanakan dakwah

c. Kisah-kisah kaum wanita dalam perjuangan agama Allah

a. Kisah wanita dari Bani Dinar

b. Kisah Ummu Sa'ad r.ha

c. Kisah Ummu Sulaim r.ha

Dalam membentuk murabbiyah, muslimah sejati yang peduli terhadap pendidikan agama anak-anaknya :

a. Kepentingan mendidik anak

b. Kewajiban mendidik anak

c. Peranan ibu muslimah dalam pendidikan anak

d. Proses awal pendidikan anak

a. Amalan ketika mengandung

b. Sikap dan adab ketika mengandung

c. Sikap dan adab ketika melahirkan dan setelahnya

d. Sikap dan adab ketika ibu menyusui anaknya

e. Memulai pendidikan anak

a. Pengaruh sikap orang tua terhadap anak

b. Ketika anak mulai berbicara

c. Ketika anak berusia empat tahun

d. Ketika anak berusia tujuh tahun

e. Ketika anak berusia 10 tahun

f. Ketika anak berusia 12 tahun hingga dewasa

g. Pendidikan akhlak dan adab

Membentuk muslimah menjadi zahidah, seorang wanita yang cinta kepada Akhirat serta kezuhudannya terhadap dunia.

a. Senantiasa takut kepada Allah

b. Sederhana dalam hal pakaian dan urusan rumah tangga

c. Sederhana dalam hal tempat tinggal

d. Senantiasa haus dan semangat terhadap amal kebaikan.

Terakhir adalah membentuk muslimah menjadi khadimah, wanita yang memiliki rasa ketaatan kepada suami dan melayani suami dengan ketaatan.

1. Memenuhi hak-hak suami

1) Menjaga ketaatan kepada suami 
2) Menjaga kehormatan

3) Menjaga harta suami

4) Menjaga lisan

2. Mengingatkan suami dalam hal ketaatan

3. Mendorong dan membantu suami dalam mengamalkan dan meperjuangkan agama.

Dengan demikian dapat digaris bawahi bahwa dalam pelaksanaan gerakan dakwah Jama'ah Tabligh di kalangan wanita dalam pembinaan keluarga muslim di kota Bandar Lampung meliputi dua hal penting :

1. Gerakan Dakwah Jama'ah Tabligh di Kalangan wanita dalam pembinaan keluarga muslim dengan cara khuruj fii sabilillah.

2. Gerakan Dakwah Jama'ah Tabligh menyampaikan beberapa materi dakwah yang berkaitan dengan pembinaan keluarga yang tertuju pada wanita.

Untuk mempermudah dalam memahami alaur pikir tentang gerakan dakwah Jama'ah Tabligh di kalangan wanita dalam pembinaan keluarga muslim di Kota Bandar Lampung perlu adanya alur pemikiran dalam penelitian ini digambarkan sebagai berikut :

\section{KERANGKA PIKIR}

\section{Gerakan Dakwah Jama'ah Tabligh}

\section{di Kalangan Wanita}

\section{Mahram haqiqi (Isteri, Anak Wanita, Ibu Wanita, Saudara Wanita)}

\section{Menggunakan Metode khuruj fii sabilillah}

\section{Pembentukan Muslimah Sejati}

\section{Membentuk muslimah yang memiliki pribadi 'alimah, 'abidah, da' iyah, murabbiyah,} zahidah, khadimah

\section{Pembinaan Keluarga Muslim}

Melalui Materi Dakwah dalam Pembentukan Muslimah yang 'alimah, 'abidah, da'iyah, murabbiyah, zahidah, khadimah

\section{Gambar 1}

Kerangka pikir Gerakan Dakwah Jama'ah Tabligh di Kalangan Wanita dalam Pembinaan Keluarga Muslim. 


\section{Simpulan}

- Berdasarkan hasil penelusuran dan pembahasan tentang analisis hukum nafkah dalam keluarga Gerakan Dakwah Jama'ah Tabligh, dapat ditarik kesimpulan bahwa: Jama'ah Tabligh merupakan sebuah gerakan dakwah yang empat ciri yang sangat menonjol, yaitu (1) murni dan autentik (dzâtiyyâh), yakni autentik sebagai panggilan Tuhan, (2) mendorong kemajuan (taqaddûmîyah), yakni kemajuan yang tetap menjunjung tinggi nilai-nilai moralitas, (3) universal (syamîlâhi) mencakup semua aspek kehidupan, memadukan tiga sistem hidup (manhaj al hayat) yang terdiri dari tiga D, yaitu Din (agama), Dunya (dunia), dan Daulah (pemerintahan negara) dan (4) menekankan prinsip-prinsip agama yang luhur dan menjauhkan diri dari perbedaan mazhab. Berdasarkan penelitian yang penulis teliti, gerakan dakwah Jama'ah Tabligh di kalangan wanita dalam pembinaan keluarga muslim bertujuan untuk peningkatan keimanan, peningkatan amal shalih, dan kesadaran diri pada kepahaman agama dalam setiap individu keluarga. Proses berjalannya dakwah melalui Metode Khuruj fii sabilillah, akan membentuk pribadi muslimah yang memiliki sifat dan sikap 'alimah, 'abidah, da' iyah, murabbiyah, zahidah, khadimah.

\section{Referensi}

A. Ilyaz Ismail, Paradigma Dakwah Sayyid Quthub Rekonstruksi Pemikiran Dakwah Harakah, (Jakarta : Penamadani, 2006)

Abdul Rosyad Shaleh, Manajemen Dakwah Islam, (Jakarta : Bulan Bintang, 1993), Cet. Ke-3

Abu Mufdal al-Raghib al-Ashifany, al-Mufradat fi Gharib Al-Qur'an, (Damaskus : Dar Qalam, tt.), Juz 1

Ahmad Anas, Paradigma Dakwah Kontemporer, Aplikasi dan Praktisi Dakwah sebagai Solusi Problematikan Kekinian (Semarang: Pustaka Rizki Putra, 2006), Cet. Ke-1

Asmuni Syukir, Dasar-Dasar Strategi Dakwah Islam (Surabaya: Al-Ikhlas, 1983)

Departemen Agama RI, Al-Qur'an dan Terjemah, (Jakarta : Maghafirah Pustaka, 2006)

Faizah \& Lalu Muchsin, Psikologi Dakwah, (Jakarta : Kencan, 2006), Edisi Pertama, Cet. Ke-2

Fathi Yakan, Kaifa Nad'u ila al-Islam, (Beirut : Muassasah al-Risalah, 1991)

Hasan Ibn Falah al-Qattany, al-Tariq ila al-Nahdah al-Islamiyyah, (Riyad : Dar alHamidi, 1993)

Husin Ismail, http://uchinfamiliar.blogspot.co.id/2009/04/strategi-dakwahmelaksanakan-instruksi.html, diakses pada tanggal 17 April 2019, pukul 11.31 WIB

Ibrahim Muhammad al-Ja'bari, Gerakan Kebangkitan Islam, alih bahasa Abu Ayyub alAnsary, (Solo : Duta Rohman, 1996)

Ilyas Ismail dan Prio Hotman, Filsafat Dakwah : Rekayasa Membangun Agama dan Peradaban Islam, (Jakarta : Prenada Media Group, 2011), Cet. Ke-1

Jhon L, Esposito, Islam The Straight Path, alih bahasa Arif Mafthuhin, (Jakarta : Paramadina, 2004)

Khairy Abusyairi, http://kmkmmedia.blogspot.co.id/2013/03/strategi-dakwahislamiyah-di-jaman.html, di akses pada tanggal 17 April 2019, pukul 10.02 WIB

Lutfhi Assyukanie, Islam Benar Versus Islam Salah, (Jakarta : Kata Kita, 2007)

M. Munir \& Wahyu Ilaihi, Manajemen Dakwah, (Jakarta : Kencana, 2009), Cet. Ke-2 
Maulana Muhammad Manshur, Masturoh, Gerakan Dawkah di Kalangan Wanita, (Bandung : Pustaka Ramadhan, 2007), Cet. Ke-1

Maulana Muhammad Ubaidillah, Keutamaan Masturah, Usaha Dakwah di Kalangan Wanita Menurut Petunjuk Sunnah, (Bandung : Pustaka Ramadhan, 2010), Jilid, Cet. Ke-1

Muhammad Abduh Tuaskial, https://rumaysho.com/12184-strategi-dakwah1.html, diakses pada tanggal 17 April 2019, pukul 11.43 WIB

Muhammad al-Ghazali, Fi Maukib al-Da'wah, (Kairo : Maktabah Nahdah al-Misr, 2005)

Musthafa Sayani, Kemulian Wanita Shalihah, (Bandung : Pustaka Ramadhan, 2004), Cet. Ke-2

Onong Uchjana Efendi, Ilmu, Teori dan Filsafat Komunikasi (Bandung: PT. Citra Aditya Bakti, 2003)

Raghib al-Ashfahani, al-Mufradat fi Gharib al-Qur'an, (Beirut Libanon : Dar alMa'rifah, tt.), h. 114. Lihat pula, Ibn Manzhur, Lisan al-Arab, (Beirut : Dar Shadir, 1990), Cet. Ke-1

Sayyid Quthub, Maalim fi al-Tariq, (Kairo : Dar al-Syuruq, 1979) Nahwa Mujtama' Islamy, (Kairo : Dar al-Syuruq, 1993) Tafsir Fi Zilal Al-Qur'an, (Mauqi al-Tafsir), Juz 4

Simi Niazi, A New Paradigm in the Making, dalam Kalim Siddiqui (Ed.) Issues in the Islamic Movement 1980-1981 (1400-1401), (London-Toronto-Pretoria : The Open Press Limited, 1982)

Sutikno, http://sutiknotaliabo.blogspot.co.id/2013/05/strategi-dakwah.html, diakses pada tanggal 17 April 2019, pukul 12.00 WIB

Syaikhul Islam Ibnu Taimiyah, Qawa'id wa Dhawabith Figh Ad-Da'wah 'Inda, (Kairo : Dar Ibnul Jauzi, tt.t, 2010), Cet. Ke-2

Wahyu Ilahi, M. Munir, Manajemen Dakwah, (Jakarta : Prenada Media, 2006), Cet. Ke.1

Yusuf al-Qardawy, Sahwat al-islamiyah wa Humun al-Watan al-'Arab wa al-Islami, (Kairo : Makhtabah Wahbah, 1997)

Yusuf Qardawy, Min Figh ad-Daulah fi al-Islam, (Kairo : Dar as-Syuruq, 2001) Syari'at al-Islam as-Salihat li al-Tatbiq fi kulli zaman wa Makan, (Kairo : Dar al-Sahwah, 1993) 